\title{
Analysis of Presumed IQOS Influencer Marketing on Instagram in the Czech Republic in 2018-2019
}

\author{
HEJLOVÁ, D. ' , SCHNEIDEROVÁ, S. ${ }^{1}$, KLABÍKOVÁ RÁBOVÁ, T. ${ }^{1}$, KULHÁNEK, A. ${ }^{2}$
}

1 | Charles University, Faculty of Social Sciences, Department of Marketing Communication and Public Relations, Prague, Czech Republic

$2 \mid$ Charles University, First Faculty of Medicine, Department of Addictology, and General University Hospital, Prague, Czech Republic
Citation | Hejlová, D., Schneiderová, S., Klabíková Rábová, T., Kulhánek, A. (2019). Analysis of Presumed IOOS Influencer Marketing on Instagram in the Czech Republic in 2018-2019. Adiktologie, 1911), 7-15;

https://doi.org/10.35198/01-2019-001-0001
BACKGROUND: Heated tobacco products (HTP) are novel electronic devices that produce an aerosol by heating modified tobacco. In July 2017, Philip Morris launched a heated tobacco product, I00S, on the Czech market. The release of IOOS was promoted by a massive marketing campaign using various marketing channels. AIM: This paper presents an analysis of the influencers' posts promoting a heated tobacco product (HTP), IQOS, produced by Philip Morris, in the Czech Republic. METHODS: Critical discourse analysis (CDA) was used to uncover the hidden power relationships in both textual and visual representations of IQOS in Instagram posts. We analysed the posts of 22 Czech influencers identified with the hashtags \#I00Sambassador, \#I0OSambasabor, \#I0OSlounge, \#IOOSveVarech, and \#mujI00S, together with associated pictures and videos on Instagram.

RESULTS: The hashtag \#iqosambassador was used internationally in 940 posts (as of May 16, 2019). Our findings show subtle forms of persuasion that associate the IQOS product with an aspirational, exclusive lifestyle, healthy living, and a relaxed atmosphere within a community of friends. Preliminary results also show that influencers promoted IOOS to any and all Instagram users (including children and non-smokers). Covert advertising was indicated indirectly by the use of hashtags (\#notriskfree, \#onlyforadults, and \#iqosambassador), which might be evidence that the influencers were paid indirectly by a digital marketing or PR agency. CONCLUSIONS: Czech celebrities and influencers have been actively presenting IOOS in their posts and videos since 2018 on Instagram. They present IOOS as a gateway to an aspirational, healthy, attractive and celebrity lifestyle. The preliminary results are being published as a part of a larger interdisciplinary research project by Charles University, Prague.

\section{Keywords | Heated Tobbaco Products - IOOS - Influencer Marketing - Covert Advertising - Critical Discourse Analysis}

Grant affiliation | This research was made possible by internal financial support from the Faculty of Social Sciences, by “Progres" 018 - Social Sciences: From Multidisciplinarity to Interdisciplinarity, a Charles University research programme, and Progres No. Q06/LF1, an institutional support programme, and from the Centre for Tobacco Use Prevention and Research, funded by the Ministry of Health of the Czech Republic. 


\section{BACKGROUND}

Tobacco companies have been struggling with a decline in their consumer base and decreasing social acceptability of smoking. For that reason, they are trying to develop new products, such as heated tobacco products (HTPs), and new marketing strategies that will help them to preserve their positions on the market, find new customers, and legitimise their core business of marketing tobacco (Bialous \& Glantz, 2018; Auer et al., 2017). According to the World Health Organisation, tobacco companies are using marketing strategies that rely on non-traditional marketing and product distribution, including "social marketing techniques involving the development of community activators and brand ambassadors, who promote HTPs through various channels" (WHO, 2018, p. 18).

Social media play a crucial role nowadays in the life of young people, and influencers are important role models for establishing modes of behaviour, including attitudes to smoking, vaping, and using HTPs (Elmore, Scull, \& Kuperschmidt, 2017; Laestadious et al., 2019; Leventhal \& Barrington-Trimis, 2018; McKelvey et al., 2018a; Measham et al., 2016). A study by Karma Kelvey et al. (2018b) proved that consumers can be misled by statements that HTPs are less harmful than traditional tobacco delivery systems into believing that HTPs are a harmless product. The Czech Republic ranks among the European countries with the highest prevalence of smoking. 25\% of the adult population are tobacco smokers (Movsisyan et al., 2016; Váňová, Skývová, \& Malý, 2018; WHO, 2017). In the Czech Republic, smoking cigarettes (other than the use of HTPs) in restaurants and public spaces was banned in May 2017. Czech law, specifically the Advertising Regulation Act, no. 40/1995, bans the advertising of tobacco products and sponsoring of events, with the exceptions of POS (point-of-sale) advertising, ads in retail publications, and advertising during automobile sporting events (Act 40/1995).

The marketing of products by online influencers has grown along with the rise of online social media and the overall changes in the media and advertising landscape. Duncan Brown and Nick Hayes (2008) defined some of the changes at the turn of the millennium; however, marketing has evolved rapidly since then. Personal recommendations and celebrity endorsements have existed since the early history of advertising, but social media have enabled the emergence of distant, online "significant others" who have gained enormous influence by creating a pseudo-friendly relationship with their online followers. (Joshua Meyrowitz predicted this as early as 1986). New influencers gain the trust of their followers by freely displaying their lifestyles on Instagram, Facebook, and other social networks. Their followers adopt them as new role models. Social media influencers capitalise on their symbolic power with their followers by selling advertising and making paid endorsements in a similar way to traditional celebrity endorsement marketing. However, they do so with a great deal more "authenticity", which makes the advertising in which they appear seem more trustworthy (Martikainen \& Pitkänen, 2019). This process is changing the whole traditional model of decision making used by marketers. Traditional media advertising is playing a lesser role, and influencer marketing has become an integral part of advertising budgets (Vinerean, 2017; Backaler, 2018). Influencer marketing not only promotes a certain product, but also shows a certain lifestyle in which the product plays a central role. It does so with greater credibility than traditional media (Lou \& Youan, 2019).

Using influencers to market tobacco products involves several legal and ethical problems:

1/ Covert Advertising: the advertising of tobacco products is banned on Instagram and Facebook (according to the conditions of use of those social media). However, influencers do in fact advertise covertly, which is basically trackable only by recognising and following specific hashtags. The use of particular hashtags reveals or states openly that a post is in reality paid advertising.

2/ Problematic Targeting: tobacco companies producing HTPs claim that they target only adult smokers and promote HTPs as "a healthier option for cigarette smokers". However, their targeting does not differentiate between smokers and non-smokers. Although the minimum legal age for the use of Instagram in the European Union is now 16 years after the enactment of the new GDPR law, many younger users lie about their age and declare they are 18+ in order to use it. 3/ Third Party Payments: it is difficult to prove that an influencer has been paid for advertising or promoting a tobacco product. Payment usually goes through third parties (such as digital marketing, PR, or advertising agencies). Moreover, contracts between influencers and tobacco producers or their agents usually do not directly state that a financial reward to the influencer is for tobacco advertising, but rather for hosting a show, performing, designing a special package, or the like.

In July 2017, Philip Morris launched a new heated tobacco product (HTP), IQOS, on the Czech market. However, there were virtually no posts or organic content promoting IQOS to be found on social media, especially Instagram, until the end of May 2018, when IQOS first became a sponsor of the Karlovy Vary International Film Festival (KVIFF) (iDnes, June 28, 2019). Figure 1 shows the increase in the number of Google searches for IQOS in the Czech Republic, which clearly corresponds with (1) the launch of the product (note that interest in the product quickly waned) and then with (2) the sponsorship and presumed campaign by influencers during the KVIFF. The green line in Figure 1 indicates searches for KVIFF, and the blue line indicates searches for IQOS. Both show a corresponding steady increase after the peak of the IQOS campaign.

The sudden interest in IQOS shown by many celebrities has been noticed and criticised by some media outlets and social media influencers for being paid influencer marketing (Těšínská, 2018; Kovy, 2018). Philip Morris has never publicly commented or confirmed that it has paid influencers to promote IQOS in the Czech Republic. However, in a recent statement the company announced that it had "suspended 

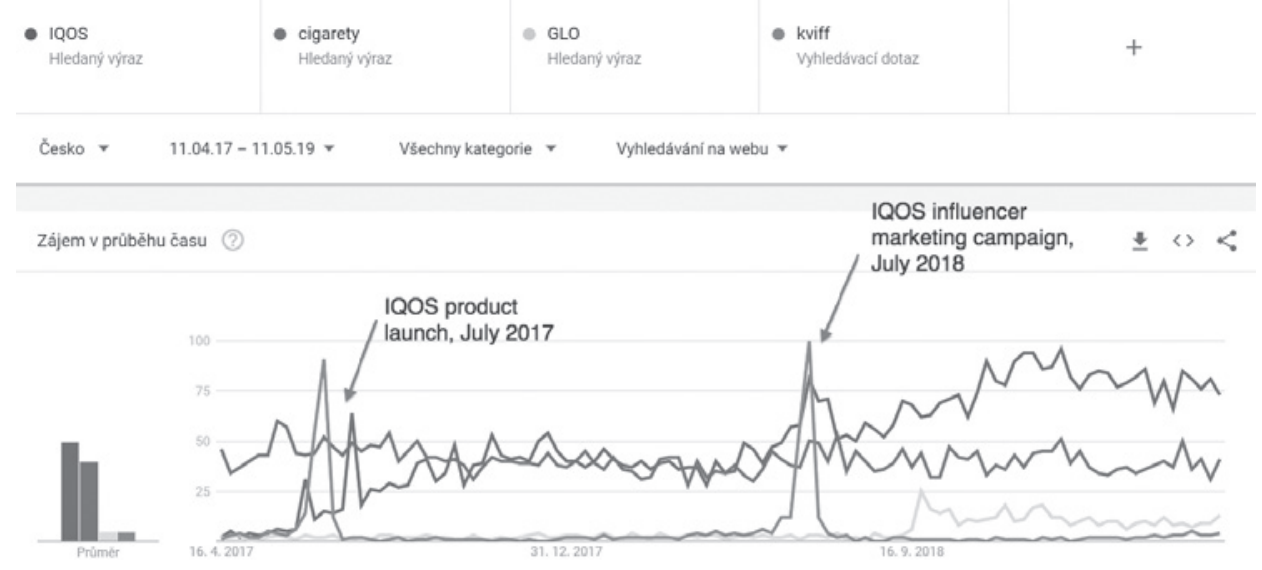

Figure 1 | Searches for IQOS on Google (April 11, 2017-May 15, 2019) Source: original analysis, Google trends.

[its] social media campaign” after experiencing a global media backlash (Reuters, May 11, 2019). The company's statement indirectly confirms that it has in fact been using influencers to promote its HTP.

The Czech Republic serves as a test market for both Eastern and Western Europe, so it is likely that if influencer marketing is successful in the Czech Republic, Philip Morris will extend it to other markets later on, and that it will be adopted by other tobacco companies as well. Philip Morris attracted 130,000 new IQOS users between July 2017 and September 2018. Its profit in the Czech Republic rose by 6.2\% to 1.7 billion CZK (approximately 74 million USD). The company has stated that its profits rose thanks in part to the successful launch of IQOS. The Czech Republic has one of the fastest adoption rates for an HTP product (ČTK, September 25, 2018).

\subsection{Defining Heated Tobacco Products}

Heated tobacco products (HTPs) are electronic devices that produce an aerosol vapour by heating modified tobacco in the form of sticks, plugs, or capsules up to $350{ }^{\circ} \mathrm{C}$ (Simonavicius, McNeill, Shahab, \& Brose, 2018). The vapour is then inhaled by the user. Although the aerosol contains fewer toxic substances than combustible tobacco (Farsalinos et al., 2018), HTPs still deliver highly addictive nicotine and other toxic and potentially harmful substances (Bekki, Inaba, Uchiyama, \& Kunugita, 2017; Davis, Williams, \& Talbot, 2018; Farsalinos, Yannovits, Sarri, Voudris, \& Poulas, 2017; Leigh, Tran, O'Connor, \& Goniewicz, 2018). Flavour additives, hi-tech electronic features in the devices, and consumer perceptions of lower harm to health contribute to the increasing appeal of HTPs for adolescents (Jenssen, Walley, \& McGrath-Morrow, 2018; Max, Sung, Lightwood, Wang, \& Yao, 2018; McKelvey, Popova, Kim, Chaffee, et al., 2018).

An exact legal definition of a "heated tobacco product" has not yet been established by the Czech Republic. Act
No. 65/2017, On the Protection of Health from the Harmful Effects of Addictive Substances (the so-called "Smokefree Law") defines HTP cartridges as a "tobacco product" (in the same category as cigarettes). According to that law, electronic HTP devices (separately, without tobacco cartridges) are legally considered to be electronic cigarettes. The smoke-free law allows the usage of heated tobacco products in public catering establishments (i.e. restaurants, pubs, bars, and cafes).

Law No. 40/1995, §3a (the so-called "Advertising Regulation Act”) bans all advertising of electronic cigarettes except for materials for sellers and specialised shops, including "the sponsoring of events, activities, or individuals with the direct or indirect aim of promoting electronic cigarettes".

\section{STUDY DESIGN AND METHODS}

We have used Critical Discourse Analysis (CDA) to analyse Philip Morris's online activity. CDA is a mainstream linguistic and social science research method that uncovers the structures and meanings embedded in (or missing from) a text (Bayley, Cameron, \& Lucas, 2013). We used a socio-cognitive approach developed by Teun van Dijk (1993, 2001, 2015). Van Dijk's approach to critical discourse analysis focuses on the "discursive reproduction of power abuse...as well as resistance against such domination" (Van Dijk, 2015, p. 466). Critical discourse analysis can be used to uncover hidden relations of power that are embedded in a text or visual representation.

\subsection{Sample}

We analysed the posts of 22 Czech celebrities or online influencers who posted content (videos or pictures) on Instagram, using the hashtags \#IQOSambassador, \#IQOSambasabor, \#IQOSlounge, \#IQOSveVarech, \#mujIQOS, or other IQOS-related hashtags. We selected 97 such posts 


\begin{tabular}{|c|c|c|c|}
\hline Name & Profile name & Occupation & $\begin{array}{c}\text { Number of followers } \\
\text { on Instagram ( } k=\text { thousand) }\end{array}$ \\
\hline Nikol Moravcová & nikolmoravcova & blogger, socialite & $95.6 \mathrm{k}$ \\
\hline Jitka Schneiderová & jitka_schneiderova & actress & $89.8 k$ \\
\hline Anna Geislerová & geislerka & actress & $86.8 \mathrm{k}$ \\
\hline Blanka Matragi & blanka_matragi_designer & fashion designer & $56.3 k$ \\
\hline Libor Bouček & liborboucek & TV host & $47.1 \mathrm{k}$ \\
\hline Yemi A. D. & yemialchemist & choreographer & $45.7 k$ \\
\hline Karel Vágner & karelvagner & PR, Marketing & $43.5 \mathrm{k}$ \\
\hline Kami Bartošek & kazma_kazmitch & TV host & $410 k$ \\
\hline Matěj Ruppert & ruppertmatej & singer & $41.8 k$ \\
\hline Dominika Reslerová & diminikaresler & hairdresser, influencer & $37.5 \mathrm{k}$ \\
\hline Simona Krainová & simonakrainova & model & $363 k$ \\
\hline Michaela Štoudková & michaelastoudkova & blogger, socialite & $32.3 k$ \\
\hline Veronika Arichteva & vronikaarichtev & actress & $289 k$ \\
\hline Vana Jandová & vandajanda & fashion designer, influencer & $27.1 \mathrm{k}$ \\
\hline Shared profile of 3 influencers & blogesrobes & bloggers & $26.2 \mathrm{k}$ \\
\hline Kristýna Políček & kristynapolicek & blogger, fashion stylist & $21.2 k$ \\
\hline Pasta Oner & pastaoner & artist & $19.4 \mathrm{k}$ \\
\hline David Gránský & davidgransky & actor & $185 \mathrm{k}$ \\
\hline$\underline{\text { David Kraus }}$ & davidkrausofficial & singer & $16.6 \mathrm{k}$ \\
\hline Marek Pavala & marekpavala & celebrity chef & $13.6 \mathrm{k}$ \\
\hline Petr Kraus & peeetaaatv & youtuber & $110 \mathrm{k}$ \\
\hline Petr Kutheil & kutheil & singer, actor & $10.5 \mathrm{k}$ \\
\hline
\end{tabular}

Figure 2 | List of Czech influencers who posted Instagram content using the hashtag \#iqosambassador or other IOOS-related hashtags (see Figure 3) from January 1 , 2018 to April 30, 2019

Source: original analysis

that contained at least one of the hashtags for inclusion in our analysis. (Figure 2.)

The hashtag \#iqosambassador was used internationally in 940 posts (as of May 16, 2019). In 40 cases it appeared in a Czech version or with the wrong spelling: \#iqosambasador, with a single "s". Other hashtags in the Czech language that indicate a relationship with the IQOS campaign are listed below. (Figure 3.)

\section{RESULTS}

Critical discourse analysis of posts containing IQOS-related hashtags showed that the product was presented positively, as a hi-tech gadget associated with an aspirational, healthy lifestyle. The product was promoted in the Czech Republic by influencers and showbusiness celebrities, who included TV hosts, actresses, designers, and socialites. There were no sports personalities, politicians, businesspeople, or doctors associated with the hashtag.

Despite Philip Morris's claim that it uses only models who are 25 years of age or older, we found Ms. Vanda Jandová (vandajanda), who was 20 years old in 2018, among the IQOS influencers, and also Petr Kraus (peeetaaatv), who we believe is under 25 years of age.
We have identified three dominant discourses which represent IQOS as (1) a host and generous donor; (2) a gateway to an aspirational, celebrity lifestyle, and (3) a part of a healthy lifestyle. We have analysed the possible targeting of children and young people by such Instagram posts, and also observed criticism and a backlash by other social media influencers against Philip Morris's presumed advertising of IQOS on social media.

\subsection{IQOS as a Host and Generous Donor}

We can identify an asymmetrical relationship between the influencers and the company, in which the company is referred to as a "host" to which the influencers are "grateful". Influencers state openly that they have received their IQOS as a gift, that "IQOS invited me", etc., which indicates a power dynamic in which the company, described as a generous partner (donor), is dominant. The influencer is described as an appreciative and grateful recipient.

IQOS is presented as a facilitator of an improvement in the influencers' lives, as a party host which gathers together a good company of friends and VIPs, and as a companion.

Online and offline celebrities express their gratitude for invitations to parties and for gifts sent by Philip Morris, which 


\begin{tabular}{lll}
\hline Czech hashtag & English translation & Number of posts \\
\hline \#jenprodospele & Only for adults & 193 \\
\hline \#iqosvevarech & IQOS in Karlovy Vary International Film Festival & 118 \\
\hline \#nenibezrizika & Not risk-free & 45 \\
\hline \#mujiqos & My IQOS & 30 \\
\hline \#mojeruby & My Ruby (new colour of device) & 28 \\
\hline
\end{tabular}

Figure 3 | Most-used IOOS-related hashtags in the Czech language (excluding \#iqosambassador, \#iqoslounge, etc.). Note: some posts used more than one hashtag. Source: original analysis

is not mentioned by name, only implied. They express thanks for a "product which has definitely changed our life for the better" and for an "invitation to a party".

\section{Example 1:}

The example below shows an online influencer and model, Nikol Moravcová, in her lifestyle blog Bloges Robes, which she shares with the stylist Kristyna Poliček and model Michaela Štoudková. The picture is captioned "new information from the world of fashion, technology, food...which might please you or make your life better". This promise clearly indicates that the bloggers intend to add some important and useful value to their readers' lives by presenting them with new information. The picture is typical of advertising, with the camera's focus on the influencer's face, her eyes capturing the gaze of the viewer, and the product placed in the centre of the frame. Promotional intent can be inferred from the hashtags \#onlyforadults and \#notwithoutrisk, as well as the photo being openly tagged with IQOScz. A comment below Moravcová's post by a different user offers a discount on IQOS if the follower uses a promotional code. (Figure 4.)

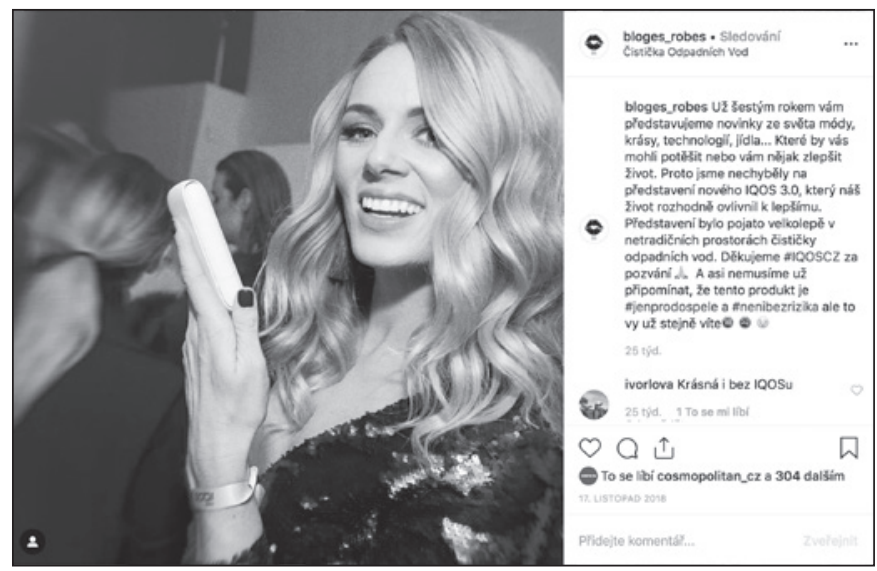

Figure 4 | IOOS as a party host

Source: Instagram, 2019

\section{Example 2, IQOS as a Gift to Influencers:}

This example shows the influencer, musician, and actor David Kraus, who is showing off a new gift he has received. Although he does not expressly mention who the donor is, he implies it indirectly in his post. The hashtags include \#iqos, \#surprise, and \#iqosambassador and are accompanied by the words: "There was a perfect gift waiting for me at the Pupp Hotel. Thank you (-)" (Note: the Hotel Pupp is the most luxurious hotel in Karlovy Vary). Kraus shows himself "unboxing" the gift, which is a popular format used by influencers to present products they have received from online shops or sponsors. However, no tobacco sticks (heets) are visible in the video - some PR professionals thus might be able to fend off criticism by arguing that Kraus is only presenting an "electronic device". (Figure 5.)

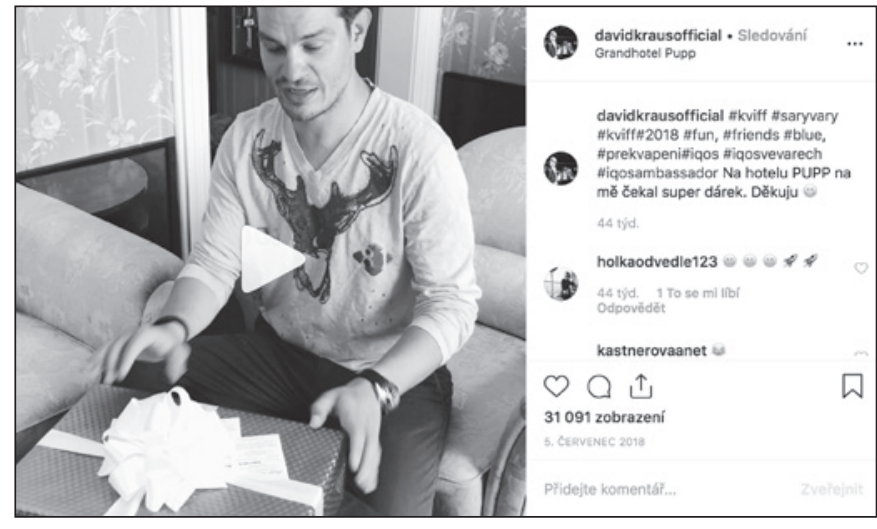

Figure $5 \mid$ IOOS as a gift

Source: Instagram, 2019

\subsection{IOOS as a Gateway to a Celebrity Lifestyle}

Another example of the "generosity" of IQOS is that it enables its celebrity users to enjoy a VIP lifestyle, thanks to IQOS hosting an exclusive party or cultural event. IQOS was a sponsor of one of the main cultural events in the Czech Republic, the 2018 Karlovy Vary International Film Festival (June-July 2018). IQOS hosted a "talkshow" with popular celebrities in its "IQOS lounge" at 6:00 p.m. every day of the festival. Coincidentally, the talkshow host, Libor Bouček, and guests such as Matěj Rupert, David Gránský, and Jitka Schneiderová, are also on our list of Czech celebrities and influencers who have posted the most Instagram posts with IQOS-related hashtags, including the \#iqosvevarech (IQOS in Karlovy Vary) hashtag.

\section{Example 3, IQOS as a Gateway to a Celebrity Lifestyle:}

The picture below presents Bouček's talkshow guests, including the popular actresses Jitka Schneiderová and 
Aňa Geislerová and the internationally acclaimed dancer Yemialchemist, who posted this "selfie". The text of the post says nothing about smoking. It states, "The talkshow... was about films, casts, dance, and the American dream. I couldn't have had better company." The persuasion in this post is very mild and indistinct, yet it is still visible in the sign on the screen behind the influencers-and in the IQOS hashtags. (Figure 6.)

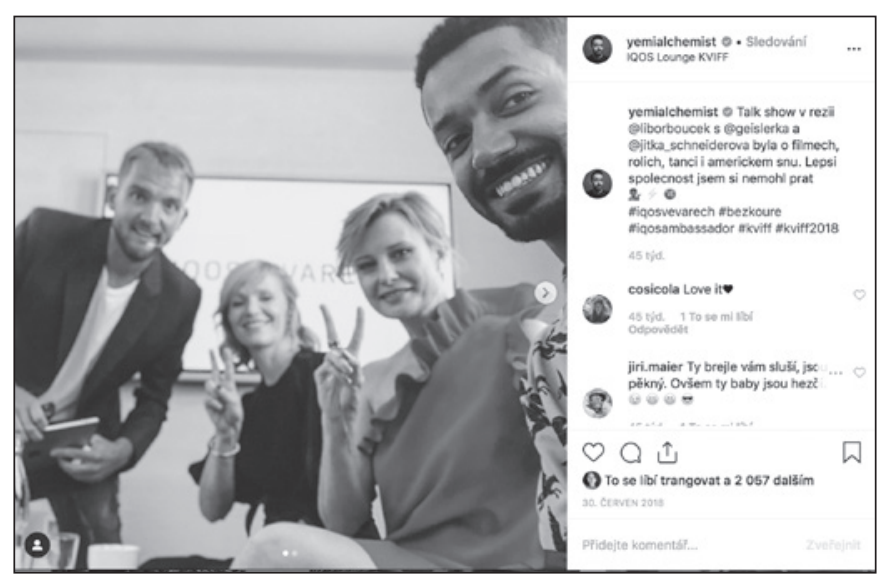

Figure 6 | I00S as a gateway to a celebrity lifestyle Source: Instagram, 2019.

\section{Example 4, Presenting IQOS on a Luxury Holiday:}

Posts from "IQOS ambassadors" that look like postcards from luxurious, exotic holidays are an interesting case. Influencers never openly mention that their holiday has been paid for or sponsored by the tobacco company. However, the text of the post proudly states that they are "Bloggers on a trip to Oman as IQOS ambassadors." (Figure 7.)

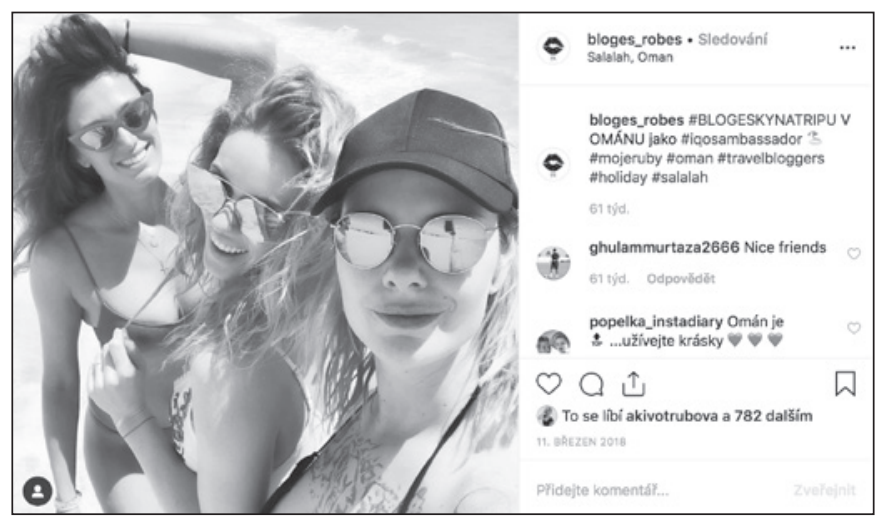

Figure 7 | Presenting IOOS on a sponsored holiday?

Source: Instagram, 2019.

\subsection{IQOS as a Part of a Healthy Lifestyle}

In numerous cases, the IQOS was presented as a part of a healthy lifestyle. It is often positioned close to healthy food and slim, fashionable, fit people. The typical setting has the IQOS lying on a table with fresh flowers or a salad. The composition of the picture often suggests that the IQOS is a very important personal object. It is either held in the hand or placed on the table in a spot where people usually put down their mobile phone. It is not unusual to see the IQOS close to a book or a relaxing drink, which associates the product with relaxation, time for oneself, and good mental health.

\section{Example 5, IQOS as a Part of a Healthy Lifestyle:}

The picture directly implies that IQOS is central to a healthy, aspirational lifestyle. The picture was taken in the fashionable Prague café Letka, which is popular among hipsters. The text states in capital letters "MONTH FOR PURIFICATION" and "It's time to give my body at least a month of well-deserved peace", followed by the hashtags \#myruby and \#iqosambassador. (Figure 8.)

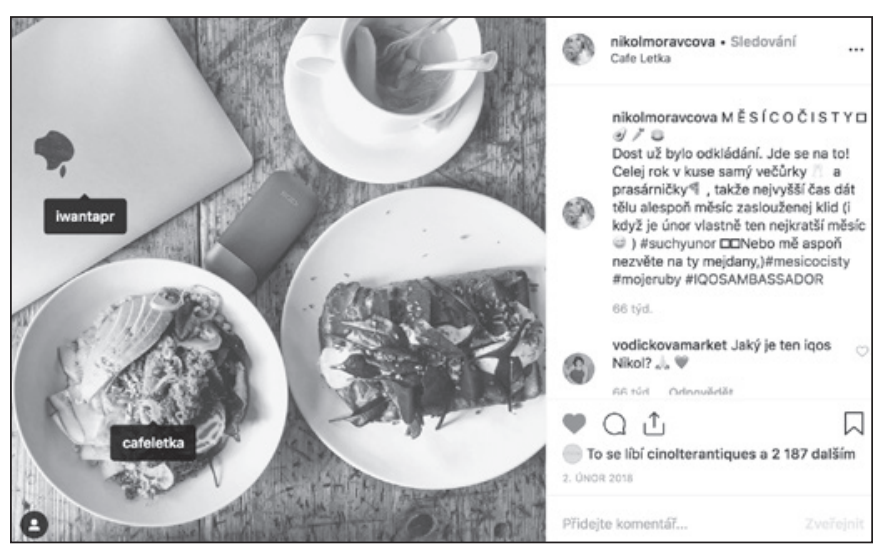

Figure 8 | IOOS as part of a healthy lifestyle

Source: Instagram, 2019.

\subsection{Presenting IQOS to Young People}

Tobacco products are strictly regulated with regard to minors. The legal age for smoking and buying tobacco in the Czech Republic is 18. However, children, especially "digital natives" (those born and brought up in the presence of digital technology), form a large segment of social media users.

The example below is a post by one of the most popular influencers with young people in the Czech Republic. Petr Kraus (@peeetaaatv) has 374,000 followers on YouTube. (The Czech Republic has only 10 million people.) Presumably, many of Kraus's followers are teenagers and younger children. His personal credo is "Bad example for kids-best YouTuber of all time".

\section{Example 6, Presenting IQOS to Young People:}

The headline of this picture states: "Hey there, are you ready for the holidays?", which is a conversation starter mostly used among elementary and high school students (because most Czech university students do not consider summer as a time for a holiday but for a part-time job). Kraus the YouTuber says: “Today it's exactly two months since I stopped smoking normal cigarettes. I don't smell like an ashtray, I can smoke in the car (as a passenger-I still don't have a li- 
cence), and overall, I have a good feeling about it. We'll see how it goes." The post has 25,000 likes. It was followed by a call for Kraus's followers to comment below the post with the answer yes or no; are they looking forward to a holiday or going on a holiday? The overall sentiment is in line with the influencer's positioning as a "cool, bad boy" with strong personal opinions. (Figure 9.)

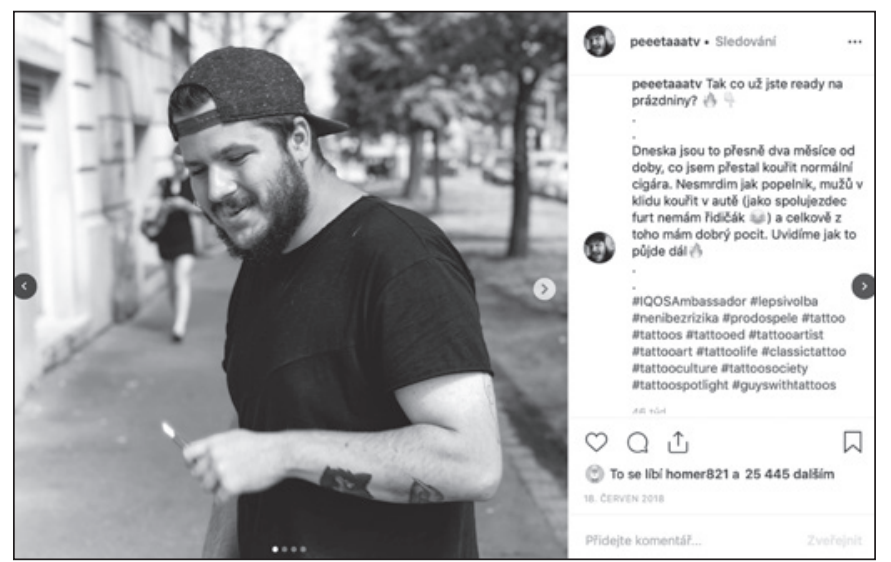

Figure 9 | IOOS presented by a Youtuber popular among young people Source: Instagram, 2019

Although the minimum age of persons to whom tobacco advertising can be directed is 25 according to the Advertising Regulation Act, no. 40/1995, among the influencers presenting IQOS we can find the model and design student Vanda Jandová, who was, according to public records, 20 years old in 2018. Jandová has displayed her passion for smoking cigarettes in her Instagram account. However, during the 2018 KVIFF she transferred her enthusiasm to IQOS, tagging herself in the post below as an "IQOSambassador". She noted her gratitude for the gift of an IQOS, "which has increased my pleasure with the IQOS, which was waiting for me in my hotel room and perfectly matches my outfit". However, after the film festival ended, the model returned to presenting herself once again as a confirmed cigarette smoker. (Figure 10.)

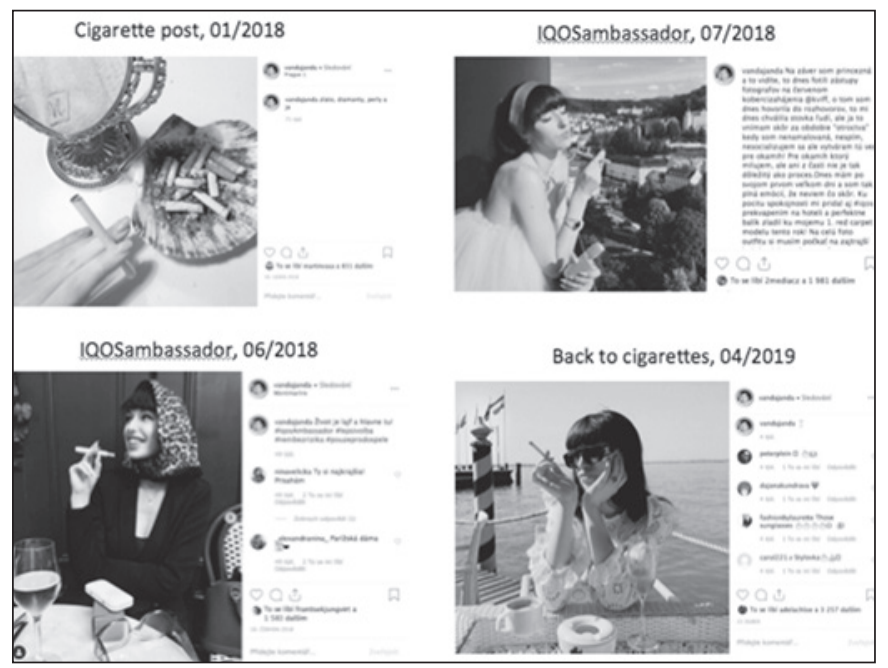

Figure 10 | IOOS presented by a 20-year-old model styled as an "IOOSambassador"

Source: @vandajanda, 2018-19, original collage.

\subsection{Influencer Backlash Against the Alleged IQOS Campaign}

Not all influencers welcomed the invasion of IQOS-related posts. The most famous Czech influencer of all, Karel Kovár̆, aka Kovy (@kovy_gameballcz), posted a video on YouTube on July 9, 2018, soon after the massive IQOS exposure during the Karlovy Vary Film Festival. In the video he accused Czech influencers of covertly advertising HTPs in the Czech Republic. However, he never actually said the name of the product, IQOS, for legal reasons. Instead he used the word "krajkos", which sounds similar. The hashtag \#krajkos subsequently became a meme for criticism of HTP influencer marketing. It has been widely used as a sarcastic comment below many \#iqosambassador posts. Kovár has stated that the influencers who use the hashtag have sunk to the "the lowest moral state" with their covert advertising of tobacco products. His video has over 618,000 views (as of May 2019) and has been cited in Czech tabloids and news media (such as Lidové noviny, on July 12, 2018).

Martina Votrubová @akivotrubova has also expressed criticism of the IQOS campaign. Some commenters using Instagram also stated their disagreement with the IQOS tobacco promotion, including a comment under Vanda Jandová's above-mentioned post. Jandová presented herself as a "princess" who is looking forward to walking the red carpet in an extravagant pink dress. The user commented: “Yuck, princesses don’t smoke, even a little kid knows that!" Jandová replied: "In MY film about princesses they do smoke."

\section{DISCUSSION AND CONCLUSIONS}

Many Czech celebrities and online influencers were actively presenting IQOS in their posts and videos in 2018 and 2019. A real-time tracker analysis of \#iqosambassador shows that three Czech Instagram influencers who are associated with IQOS are among the nine influencers with the greatest global engagement. Petr Kraus @peeetaaatv was number two with 20,013 average engagements per post, David Gránský @davidgransky, with 8,965, was number eight, and Veronika Arichtevová @veronikaarichtev, with 8,264, was number nine (information from the Campaign for Tobacco-Free Kids, 2019 and Hejlová, 2019). All three presented IQOS as a gateway to an aspirational, healthy, celebrity lifestyle, associated with fun, friends, and exotic locations and experiences. The influencers have a real impact on lifestyle and life aspirations, especially for digital natives. They also serve as role models for young people. The IQOS campaign has been reported upon by mainstream media and also criticised by some influencers, such as Karel Kovár @kovy_gameballcz and Martina Votrubová @akivotrubova.

We used the method of critical discourse analysis (Van Dijk, 1993; 2015), which has some limitations (Breeze, 2011). CDA is a qualitative approach, not a quantitative one, so it is not conducive to drawing quantitative conclusions or generalising the results. The data should ideally be ana- 
lysed using quantitative content analysis (Riff, Lacy, \& Fico, 2014) as well, which might show new results. Additionally, we focused our interest only on Instagram, which is the most widely used social network in the Czech Republic after Facebook (ahead of Twitter, for example). It would be interesting to explore other social media, such as YouTube and Tik Tok, which targets a younger audience.

Our results are mostly consistent with the findings of other research by international scholars (Auer, Concha-Lozano, Jacot-Sadowski, Cornuz, \& Berthet, 2017; Bialous \& Glantz, 2018; Jenssen et al., 2018; McKelvey, Popova, Kim, Lempert, et al., 2018). They describe other HTP campaigns for products that are marketed internationally as a new technology with health benefits and advantages for achieving an aspirational modern lifestyle.
In conclusion, the tobacco industry's advertising has clearly misused the rapid evolution of social media, especially Instagram. It has used influencer marketing to show its new HTP product in a favourable light, as an indispensable part of an exclusive, healthy, aspirational lifestyle. The tobacco companies have crossed the legislative and ethical lines that apply to other tobacco products such as cigarettes, and even e-cigarettes, and seem to be advertising HTP products to young audiences. Although our research did not surface any evidence of payments to influencers, we have found critical discourse analysis to be an effective tool for analysing power relations, which show influencers in a submissive position vis-à-vis the tobacco companies with their effusive expressions of gratitude to the companies for providing them with extravagant gifts (and presumably, income as well).
Acknowledgements: The authors wish to thank the student research assistants Huu Nguyen, Adam Kilberger, and Filip Matějka, and Prof. Eva Králíková, Institute of Hygiene and Epidemiology, First Faculty of Medicine, Charles University and General University Hospital, for consultation.

Authors' contribution: The research team consisted of Denisa Hejlová (team leader), Soňa Schneiderová, Tereza Klabíková Rábová (team members, all from the Department of Marketing Communication and Public Relations at Charles University), and Adam Kulhánek (Head of the Centre for Tobacco Use Prevention and Research of the First Faculty of Medicine, Charles University and General University Hospital). All the authors contributed to the final version of the manuscript and approved it.
Declaration of interest: No conflicts of interest. All team members state that they have no conflict of interest and that they have been supported neither by the tobacco industry, nor its lobby groups. The research is funded by internal financial support from the Faculty of Social Sciences.

\section{REFERENCES}

Auer, R., Concha-Lozano, N., Jacot-Sadowski, I., Cornuz, J., \& Berthet, A. (2017). Heat-Not-Burn Tobacco Cigarettes: Smoke by Any Other Name. JAMA Intern Med, 177(7), 1050-1052. doi:10.1001/jamainternmed.2017.1419

Backaler, J. (2018). Then vs. Now: Influencer Marketing (Re-) Defined. In Digital Influence (pp. 5-18). Palgrave Macmillan, Cham.

Bayley, R., Cameron, R., \& Lucas, C. (2013). The Oxford Handbook of Sociolinguistics. OUP USA.

Bekki, K., Inaba, Y., Uchiyama, S., \& Kunugita, N. (2017). Comparison of Chemicals in Mainstream Smoke in Heat-not-burn Tobacco and Combustion Cigarettes. J uoeh, 39(3), 201-207. doi:10.7888/juoeh.39.201

Bialous, S. A., \& Glantz, S. A. (2018). Heated tobacco products: another tobacco industry global strategy to slow progress in tobacco control. Tob Control, 27(Suppl 1), s111-s117. doi:10.1136/tobaccocontrol-2018-054340

Breeze, R. (2011). Critical discourse analysis and its critics. Pragmatics, 21(4), 493-525. doi: https://doi.org/10.1075/prag.21.4.01bre

ČTK (2018, September 25). Philip Morris v Česku zvýšil zisk o více než šest procent na 1,7 miliardy, hlavně díky bezdýmným tabákovým výrobkům | Hospodářské noviny (IHNED.cz). Retrieved on 24 May 2019 from https://byznys. ihned.cz/c1-66257380-alternativni-cigarety-tahnou-philip-morris-v-cesku-zvysilzisk-o-vice-nez-sest-procent-hlavne-diky-bezdymnym-tabakovym-vyrobkum.

Davis, B., Williams, M., \& Talbot, P. (2018). iO0S: evidence of pyrolysis and release of a toxicant from plastic. Tob Control. doi:10.1136/ tobaccocontrol-2017-054104

Elmore, K. C., Scull, T. M., \& Kupersmidt, J. B. (2017). Media as a “Super Peer": How Adolescents Interpret Media Messages Predicts Their Perception of Alcohol and Tobacco Use Norms. Journal of Youth and Adolescence, 46(2), 376-387. https://doi.org/10.1007/s10964-016-0609-9
Farsalinos, K. E., Yannovits, N., Sarri, T., Voudris, V., \& Poulas, K. (2017). Nicotine delivery to the aerosol of a heat-not-burn tobacco product: comparison with a tobacco cigarette and e-cigarettes. Nicotine Tob Res. doi:10.1093/ntr/ntx138.

Farsalinos, K. E., Yannovits, N., Sarri, T., Voudris, V., Poulas, K., \& Leischow, S. (2018). Carbonyl emissions from a novel heated tobacco product (IQOS): comparison with an e-cigarette and a tobacco cigarette. Addiction. doi:10.1111/add.14365.

Gilman, S. L., Gilman, G., Xun, Z., Gilman, S. I., \& Zhou, X. (2004). Smoke: A Global History of Smoking. Reaktion Books.

Greenland, S. J. (2016). The Australian experience following plain packaging: the impact on tobacco branding. Addiction, 111(12), 2248-2258. https://doi.org/10.1111/add.13536

Hair, E. C., Bennett, M., Sheen, E., Cantrell, J., Briggs, J., Fenn, Z., Vallone, D. (2018). Examining perceptions about IOOS heated tobacco product: consumer studies in Japan and Switzerland. Tobacco Control, 27(Suppl 1), s70-s73. https://doi.org/10.1136/tobaccocontrol-2018-054322

Hayes, N. (2008). Influencer Marketing: Who Really Influences Your Customers? Taylor \& Francis.

Hejlová, D. (2019). I00S přestane platit influencery. (2019, květen 21). Retrieved on 26 May 2019 from Markething.cz website: http://markething.cz/iqos-prestane-platit-influencery.

Jenssen, B. P., Walley, S. C., \& McGrath-Morrow, S. A. (2018). Heat-not-Burn Tobacco Products: Tobacco Industry Claims No Substitute for Science. Pediatrics, 141(1). doi:10.1542/peds.2017-2383

KOVY. (2018). Kouření. Retrieved from https://www.youtube.com/ watch?v=Csmmc4-RtiE 
Laestadius, L. I., Wahl, M. M., Pokhrel, P., \& Cho, Y. I. (2019). From Apple to Werewolf: A content analysis of marketing for e-liquids on Instagram. Addictive Behaviors, 91, 119-127. https://doi.org/10.1016/j.addbeh.2018.09.008

Leigh, N. J., Tran, P. L., O'Connor, R. J., \& Goniewicz, M. L. (2018). Cytotoxic effects of heated tobacco products (HTP) on human bronchial epithelial cells. Tob Control, 27(Suppl 1), s26-s29. doi:10.1136/tobaccocontrol-2018-054317

Leventhal, A. M., \& Barrington-Trimis, J. L. (2018). New Tobacco Products with Fewer Advertising Restrictions and Consequences for the Current Generation of Youths. JAMA Pediatrics, 172(5), 414-416. https://doi.org/10.1001/jamapediatrics.2018.0101

Lou, C., \& Yuan, S. (2019). Influencer marketing: How message value and credibility affect consumer trust of branded content on social media. Journal of Interactive Advertising, 1911), 58-73. http://dx.doi.org/doi: 10.1080/15252019.2018.1533501

Martikainen, I., \& Pitkänen, A. (2019). The Significance of Consumers' Perceived Authenticity to Engagement: Explorative Research of Influencer Marketing in Instagram. (Dissertation). Retrieved from http://urn.kb.se/resolve?urn=urn:nbn:se:liu:diva-157376

Max, W. B., Sung, H.-Y., Lightwood, J., Wang, Y., \& Yao, T. (2018). Modelling the impact of a new tobacco product: review of Philip Morris International's Population Health Impact Model as applied to the IOOS heated tobacco product. Tob Control, 27(Suppl 1), s82-s86. doi:10.1136/tobaccocontrol-2018-054572

McKelvey, K., Popova, L., Kim, M., Lempert, L. K., Chaffee, B. W., Vijayaraghavan, M., ... Halpern-Felsher, B. (2018). I00S labelling will mislead consumers. Tob Control. doi:10.1136/tobaccocontrol-2018-054333

Measham, F., O'Brien, K., \& Turnbull, G. (2016). "Skittles \& Red Bull is my favourite flavour": E-cigarettes, smoking, vaping and the changing landscape of nicotine consumption amongst British teenagers - implications for the normalisation debate. Drugs: Education, Prevention and Policy, 23(3), 224-237. https://doi.org/10.1080/09687637.2016.1178708

Meyrowitz, J. (1986). No sense of place: The impact of electronic media on social behavior. Oxford University Press.

Movsisyan, N. K., Sochor, O., Kralikova, E., Cifkova, R., Ross, H., \& LopezJimenez, F. (2016). Current and past smoking patterns in a Central European urban population: a cross-sectional study in a high-burden country. BMC Public Health, 16, 571. doi:10.1186/s12889-016-3216-5

PubMed entry. (b.r.). Retrieved from http://www.ncbi.nlm.nih.gov/ pubmed/30209207
Riff, D., Lacy, S., \& Fico, F. (2014). Analyzing Media Messages: Using Quantitative Content Analysis in Research: Taylor \& Francis.

Rosen, L. J., \& Kislev, S. (2018). I00S campaign in Israel. Tobacco Control, 27(Suppl 1), s78-s81. https://doi.org/10.1136/tobaccocontrol-2018-054619.

Simonavicius, E., McNeill, A., Shahab, L., \& Brose, L. S. (2018). Heat-not-burn tobacco products: a systematic literature review. Tob Control. doi:10.1136/ tobaccocontrol-2018-054419

Těšínská, M. (2018, September 12). Známé osobnosti dělají z kouření náhražky cigaret trend | Téma. Retrieved on 24 May 2019 from Lidovky.cz website: http://ceskapozice.lidovky.cz/zname-osobnosti-delaji-z-koureni-nahrazky-cigarettrend-p29-/tema.aspx?c=A180830_154334_pozice-tema_lube.

The Handbook of Discourse Analysis | Wiley Online Books. (b.r.) Retrieved on 24 May 2019 from https://onlinelibrary.wiley.com/doi/ book/10.1002/9781118584194.

Van Dijk, T. A. in Wodak, R., \& Meyer, M. (2001). Methods of Critical Discourse Analysis, Vol. 1. Oxford: Oxford University Press.

Van Dijk, T. A. (1993). Principles of Critical Discourse Analysis. Discourse \& Society, 4(2), 249-283. https://doi.org/10.1177/0957926593004002006.

Van Dijk, T. A. (2015). Critical discourse analysis. The handbook of discourse analysis, 466-485.

Váňová, A., Skývová, M., \& Malý, M. (2018). Uživání tabáku v České republice 2017. Retrieved from http://www.szu.cz/uploads/documents/szu/aktual/ uzivani_tabaku_2017.pdf

Vinerean, S. (2017). Importance of strategic social media marketing. Expert Journal of Marketing, 5(2), 28-35.

Vlková, J. (2018, June 28). Bartoška: Nejvíc nás pokaždé stojí ubytování pro hosty festivalu - iDNES.cz. Retrieved on 24 May 2019 from https://www.idnes.cz/ekonomika/domaci/jiri-bartoska-festival-karlovy-varysponzori-cez-ubytovani.A180625 410714_ekonomika_rts

WHO (2017). WHO report on the global tobacco epidemic, 2017: Monitoring tobacco use and prevention policies. Retrieved from Geneva: http://www.who.int/tobacco/global_report/2017/en/

WHO. NMH-PND-18.7-eng.pdf. (b.r-a). Retrieved from https://apps.who.int/iris/ bitstream/handle/10665/273459/WHO-NMH-PND-18.7-eng.pdf 